\title{
Development, disasters, and emergencies in public health
}

\author{
Carlos Machado de Freitas¹, Simone Santos Oliveira1, Christovam Barcellos²
}

DOI: 10.1590/0103-11042020E200I

IN APRIL 2019, THREE MONTHS AFTER THE DISASTER CAUSED BY VALE, which hit Brumadinho with hundreds of deaths and affected dozens of other municipalities with the tailings mud and its contaminants along the Paraopeba River, we began to prepare this special issue of the journal 'Saúde em Debate', with the theme: Development, Disasters, and Emergencies in Public Health. Our initial objective was to combine academic research and public debate on different types of disasters and health emergencies, including climate emergencies, in the same number. Although interconnected, these events and processes are usually approached differently, by different scientific traditions and organizations in society. At the same time, although they are expressions of the processes of social and economic development, at the global, national, regional, and local levels, they are often treated as if they were only the result of technological failures or events and processes in nature.

That same year, as of the end of August, Brazil was surprised by the first places hit with stains of crude oil on the beaches, mainly affecting the coast of the Northeast, reaching the coast of Espírito Santo and Rio de Janeiro, reaching more than 2,500 kilometers of beaches and constituting one of the biggest disasters of this type in terms of territorial extension.

Still in December 2019, we had the identification of a new disease, the Covid-19, which came to be declared a global pandemic on March 11,2020. Since then, the country has become one of the epicenters of the pandemic of such disease, standing out among the countries with the highest number of cases and deaths.

In the disaster in the mountainous region in 2011, considered one of the most serious in terms of immediate deaths, 918 deaths were officially registered. In the disaster caused by Vale in Brumadinho, in 2019, considered one of the most serious in mining dams, 270 deaths were officially registered. On May 19 this year, we surpassed, for the first time, the mark of more than a thousand deaths registered in a single day during the Covid-19 pandemic. From the first death by the disease, on March 17th, up to May 18th, there were 16,792 deaths, with an average of 263 deaths per day, that is, a Vale disaster in Brumadinho per day in about two months. From May 19th to July 20th, 62,149 deaths were recorded, with an average of 986 deaths per day, that is, one disaster in the mountainous region per day.

The survey of those numbers is relevant so that the impacts of these events are not naturalized, in which the number of lives lost is only one of the indicators. It is also important to help us reflect on why the same country that today is one of the epicenters of the Covid-19 pandemic has also recorded the most critical mining dam disasters, one of the most serious involving heavy rains and landslides, one of the largest in coastal and territorial extension involving crude oil spill. Disasters, epidemics, and pandemics do not exist in a vacuum; its
1 Fundação Oswaldo Cruz (Fiocruz), Escola Nacional de Saúde Pública Sergio Arouca (Ensp) - Rio de Janeiro (RJ) - Brasil. caco.de.freitas@gmail.com

2 Fundação Oswaldo Cruz (Fiocruz), Instituto de Comunicação e Informação Científica e Tecnológica em Saúde (Icict) - Rio de Janeiro (RJ), Brasil. 
causes, consequences, and capacities for social responses, including those related to health systems, constitute the realization of social and economic development processes that also produce vulnerabilities and risks ${ }^{1,2}$.

The articles published in this issue address several aspects related to understanding and strategies to reduce the risks of disasters and emergencies in public health. We hope that its reading will contribute to strengthening the country project that is expressed in the objectives of our 1988 Federal Constitution, which are to build a free, just, and solidary society, in which national development is coupled with the eradication of poverty and marginalization, aimed at reducing social and regional inequalities. It is as part of this nation project that collective health is inserted and that the Unified Health System is born, with its principles of universality, equity, and integrality.

\section{Collaborators}

Freitas CM (0000-0001-6626-9908)*, Oliveira SS (0000-0002-1477-749X)* and Barcelos C (0000-0002-1161-2753)* have equally contributed to the elaboration of this manuscript.

\section{References}

1. Blaikie P, Cannon T, Davis I, et al. At Risk: Natural Hazards, People's Vulnerability and Disasters. London: Routledge; 1994.
2. Garrett L. A próxima peste: as doenças de um mundo em desequilíbrio. Rio de Janeiro: Nova Fronteira; 1995. and Contributor ID). 